\title{
Developing a Culture of Health and Safety on Construction Projects Framework in Nigeria
}

\author{
Fatemeh Nouban and Serah Onuh John \\ Faculty of Civil and Environmental Engineering \\ Near East University, 99138 Nicosia (via Mersin 10, Turkey), Cyprus.
}

\begin{abstract}
Managing health and safety on construction sites has always been a challenging issue faced by the Nigerian construction industry. Safety conditions on the construction sites depends on type or nature of work to be carried out and the management make commitment to implement safety projects concerning construction. There are no requirements assigned for implementing a security management system by the Nigerian government. Construction industries lacked a framework to implement security regarding projects on construction sites. Developing a Safety Framework can help professionals involved in carrying out construction works, implement and improve safety practices in executing their projects on sites. This study presents the development of a structure for implementing an effective health security on construction sites. An extensive review of the literature was carried out to design an appropriate security framework. The results underscore the requirement for competent personnel who must be appointed to ensure safety on construction sites. Finally, a security framework was developed in which companies can accept and adhere. The results of this research will help Nigerian construction companies to improve safety on construction sites.
\end{abstract}

Keywords:- Health, safety, accident, construction industry, nigeria.

\section{INTRODUCTION}

The construction industry has the highest accidents and fatalities than any other industries in the world and the chance for accidents to occur in the construction sites in Nigeria is very high. Although Nigeria has the African the largest construction products markets and the country requires adequate infrastructure to supports and maintain its economic, however, amount of accidents in the construction industry is worrisome, even though the construction site accident data is scanty in the country because the cases are not reported to the relevant agencies [1], 5-7\% of the country's construction workforces are lost to the construction accidents [2]. The incidences are majorly ascribed to the lack of coherent construction safety standard package in the country to ensure that materials used, tools, machinery and handling techniques are not exposing workers to the serious injury because all come with their dangers which put construction workers at stakes especially the substandard materials are considered the principal caused of the construction failure. Furthermore, the lack of client capability to afford the best quality materials lead to the use of materials that pose conspicuous health hazards. Inadequate knowledge, fatigue thus, lack of focus psychologically or distracted by other activities, illhealth and site condition are all connected to the construction site accident. A study conducted by Oluwale Alfred et al, [2] revealed that from such psychological health, workmanship and tools handling, and material standard, contingencies, and absence of health and safety code and management are the major factors causing occupational hazards and accidents in Nigeria thus, losing its skilled workforce into avoidable construction sites accidents [2] and causing enormous cost to the Nigerian construction industries.

Construction contractors or companies always strive to get maximize their profit by neglecting the importance of maintaining the health and safety of the construction site [3-4] which resulted to the accidents that can cause fatal injuries to workers which could cause them long and short term disabilities and the frequent occurrences of accidents could disrupt the construction progress and delay the project completion fanatical loses and the reputational damage for the construction company, hence it is important to understand causations of accidents to find proper solutions. Considering and ensuring maximum safety and health management is indispensable for construction projects execution. Therefore, the critical proposition of any construction company to any project is not executing the project on time, within the budget but also hazards and accidents free [5-6].

Construction safety and health management system is essential because it is a thorough and efficient way of identifying and managing construction sites accidents causes [7]. Construction safety and health management system should be Nigerian construction company culture by including the construction companies' legislation for ensuring a healthy and safe working environment.

Lack of complying or absence of safety regulation in the country necessitated the construction health and safety culture needs in the Nigerian building environment.

Maintaining proper safety standards in a construction site is a complicated task, there is always high risk involved in construction activities such as work at heights, heavy machinery operations and heavy material handlings and working in confined spaces. Due to construction industry 
continually changing conditions, circumstances and specific risks related to those particular circumstance's and company policies could also influence the safety standards of construction sites. Accidents occur due to arbitrary interaction of many influential factors [8], such as hazardous site conditions and inadequate safety protocols but study conduct by health and safety executive (HSE) in 2003 demonstrate how influential individual worker altitudes can be to decide the final outcome of an accident, study further reveals workers attitudes contribute over approximately $75 \%$ for the final outcome of an accident, Lufer and Ledbettar [9] also reveals how workers attitudes and behaviors contribute to the large portion of a final outcome of an accident, however Langford [10] suggest a high level of influence management interaction and social pressures contribute to large portion of an outcome of a accidents and reoccurrence if accidents, according to those studies main reasoning behind this is, in a hazardous working conditions workers adapt themselves to work in such conditions if management allowed such conditions to exists, hence supervisors and managers also could have an influential contribution to construction site accidents and unsafe behavioral attitudes of workers, this further demonstrate the fact that the workers individual behaviors alone is not the only factor that contribute to causation of accidents, it is vital to understanding workers mindset regarding accidents and site safety.

Agwu and Olele [1] evaluate the Nigerian construction safety culture using safety culture method steps [11] illustrated in Figure 2. Twelve construction companies' workers are selected from six geopolitical zones in Nigeria to represent the opinion country's construction workers in evaluating the construction site accidents in Nigeria because of the lack or inadequate health and safety consideration. A descriptive study which lasts for about 13 months revealed that the construction sites accidents in Nigeria are attributed to the inadequate legislation on health and safety in the Nigerian building environment, thereby, increasing the rate of accident, therefore, death. Therefore, the objective of this research is to develop health and safety framework for Nigerian building environment which aims to come up with a national guide needed by construction industries to take responsibility for construction health and safety. The study may develop a new framework or audit of existing framework focusing more specifically on the following:

$>$ Things that all construction workers and industries should know and understand whenever taking any construction work

$>$ What all construction workers and industries should be able to do when carrying out their construction works.

Describing construction health and safety requirements will provide a useful starting point for construction sitesbased training.

\section{APPROACH}

The research study is based on the Agwu and Olele [1] where the Nigerian construction companies' key personnel are interviewed on the construction health and safety management. This study utilized Agwu and Olele [1] results which necessitate a holistic health and safety culture in the Nigerian construction industry to develop a construction health and safety framework, which is a useful tool for implementing safety on construction sites Nigeria. In developing construction health and safety culture framework for Nigeria following the EU Agency for Safety and Health Work Fact Sheet [12] key properly performing health and safety management systems are considered:

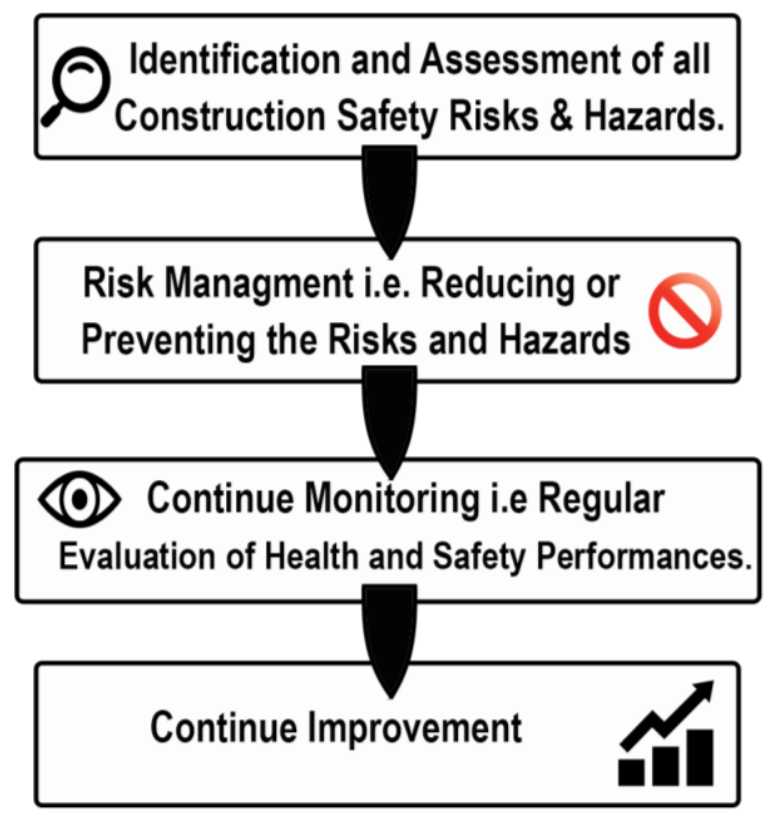

Fig 1:- Key Properly Performing Health and Safety Management Systems

\section{RESULT AND DISCUSSION}

Nigeria's Based on the performing health and safety management systems approach the study discovered that the instilling sound health and safety culture in the Nigerian building environment is the means to achieving maximum construction health and safety in Nigeria since the accidents originate from unsafe acts and condition. The process of instilling the health and safety culture in the Nigerian building environment is discussed below which are summarized in Figure 2.

The study discovered that to impacted the workers, health and safety must be a core value of the construction industries, the industries must inculcate the health and safety idea at every level of management. The top officials must take an active and palpable role in implementing the culture of health and safety within their organisation. Establishing a project safety committee with manage as a resource person who will continue to scrutinize and enhance the efforts of everyone on-site can go a long way in preventing and reducing the construction site hazard. or 
accidents. However, everyone on site is responsible for safety i.e. from site security to foremen, supervisors and managers must be held accountable for site health and safety. Therefore, discipline must be part of whole construction the processes because without accountability, the workers will not take the safety serious, thus make it their habits.

The study further identifies that staring any construction project, a specific safety plan for the project should be developed to provide an insight on the work i.e. nature of the work, roles and responsibilities of every worker from labourers to key personals. Health and safety plan should include emergency responders in case of emergency evacuation or retrieval, drugs testing and orientation for the new workers must be included. Moreover, each subcontractor of the project must have the project health and safety manual and each subcontractor will be asked to develop their safety plans for the work on how to make the project as safe as possible. However, the subcontractors' previous safety history must be reviewed before qualifying him/her for the job.

Workers training is further identified by the studies as the most effective way to handle equipment's and machines properly, in-depth safety requirements and expectations, and to understand the appropriate regulations. This should be constant and culture of the industry.

Study emphasis that no operation should commence without providing details and approval of fall management plans where the potential of fall from elevation is evident.

Substance abusing is another issue to combat, subjecting workers to tests will help in identifying those with the problem of illegal substance use and help them with the treatment and rehabilitation programs. As a project progresses, ensuring that desirable work and safety equipment is on hand through performing safety task analysis is another issue identified by the study.

During the work shift, the foremen should collect the workers in one place at the beginning of a shift and tell enlighten them the nature of the day's work with reviewing the risks involved and the health and safety controls, and assure them that the workers have the right protective gear and that all safety issues are addressed. They should understand that accidents are not inevitable. If there is an accident, the root causes must be reviewed and identified and concrete action must be taken to prevent the future occurrences. The near-misses should be given the same attention.

Lastly, the risk management insurers, engineering regulations will help construction companies' health and safety efforts, even more robust.

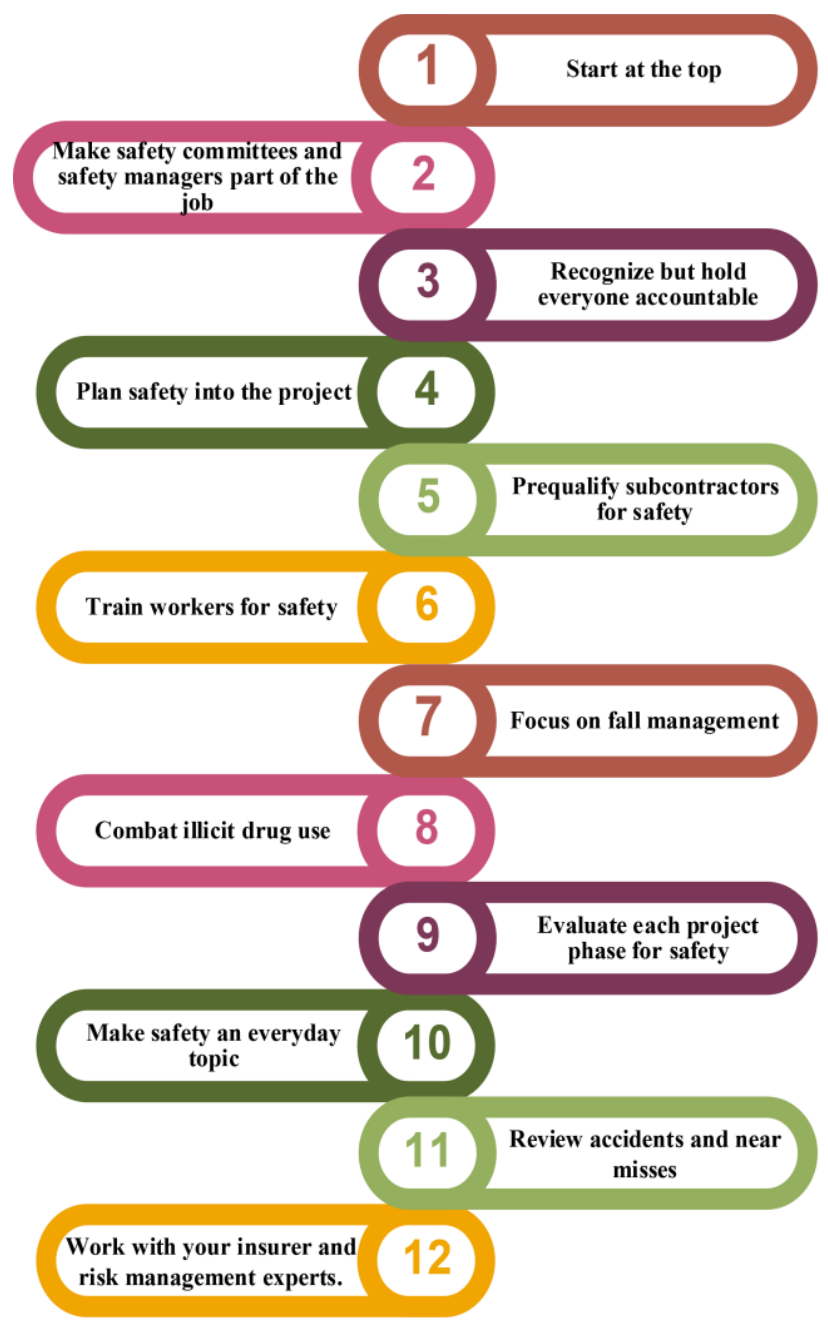

Fig 2:- Construction Health and Safety Culture Framework in Nigeria

\section{CONCLUSION}

Culture of construction projects' health and safety framework in Nigeria enables us to understand the importance of health and safety instillation in Nigeria construction industries business of the following three reasons:

Moral obligation: no construction company should risk it works and there are no excuses of whatsoever to that. Always safety first. The company must ensure the health and safety compliances because poor health and safety regulation can lead to accidents, thus, illness and even death.

$>$ Legislation: the construction companies sole and legal responsibility is to ensure safe and secure working atmosphere for its workers through implementing and maintaining rigorous health and safety protocols always.

$>$ Cost-effectiveness: Dealing with construction accidents afterwards is more than the time, effort, and cost of preventing accidents. Therefore, preventing ensuing accident will save time, efforts and money 
If the aforementioned are undertook seriously and imbibed by the construction companies and contractors in Nigeria, construction sites accidents will become a thing of the past.

\section{REFERENCES}

[1]. Mba Okechukwu Agwu and Hilda Enoh Olele. (2013). Fatalities in the Nigerian Construction Industry: A Case of Poor Safety Culture. British Journal of Economics, Management \& Trade 4(3): 431-452.

[2]. Olatunji Oluwale Alfred, Aje Olaniyi Isaac and Odugboye Femi. (2007). Evaluating Health Safety Perfomance of Nigerian Construction Site. CIB World Building Congress, CIB2007-051

[3]. Mullen, J. (2004). Investigating factors that influence individual safety behavior at work. 1st ed. [ebook] ResearchGate, p.12. Available at: https://www.researchgate.net/publication/8420801_In vestigating_factors_that_influence_individual_safety_ behavior_at_work [Accessed July 18, 2020].

[4]. Sundaytimes.lk. (2018). Men at work, but little safety at construction sites | The Sunday Times Sri Lanka. [online] Available http://www.sundaytimes.lk/160911/news/men-atwork-but-little-safety-at-construction-sites208214.html [Accessed July 18, 2020].

[5]. Sunday Observer. (2018). Minimising fatal accidents in the construction industry. [online] Available at: http://www.sundayobserver.lk/2016/10/30/business/m inimising-fatal-accidents-construction-industry

[Accessed July 18, 2020]

[6]. Darshana, W. (2015). Improvement of Health and Safety in Construction Sites in Sri Lanka. 1st ed. [ebook] The Institution of Engineers, Sri Lana, p.18. Available at: https://engineer.sljol.info/articles/10.4038/engineer.v5 0i1.7244/galley/5738/download/ [Accessed july

[7]. Labourdept.gov.lk. (2019). Industrial Safety Division. [online] Available at: http://www.labourdept.gov.lk/index.php?option=com content\&id=54\&Itemid=80\&lang=en [July 17, 2020].

[8]. H. A., Kiggundu, B. M. and Tindiwensi, D. (2000) An Investigation into the Causes of Accidents in the Construction Industry in Uganda -2nd International Conference On Construction In Developing Countries: Challenges Facing The Construction Industry In Developing Countries [online] Available at http://buildnet.csir.co.za [Accessed July 18, 2020].

[9]. Laufer A, Ledbetter WB. Assessment of safety performance measures at construction sites. Journal of Construction Division, ASCE. 1986;112(4):530-542.

[10]. Langford, D. (2008). Safety behaviour and safety management: Its influence on the attitudes of workers in the UK construction industry. 1st ed. [ebook] ResearchGate, p.10. Available at: https://www.researchgate.net/publication/229569352_ Safety_behaviour_and_safety_management_Its_influe nce_on_the_
attitudes_of_workers_in_the_UK_construction_indust ry [Accessed July 18, 2020].

[11]. European Agency for Safety and Health at Work. Luxembourg: Office for Official Publication of the European Communities; 2002.

[12]. EU Agency for Safety and Health Work Fact Sheet. Health and Safety on Small Construction Site. ISSN 168-2123 P(48). Available at file://C:/Users/SPACE/Downloads/Factsheet_48__Health_and_safety_on_small_construction_sites.pdf. Retrieved at July 17, 2020. 